\title{
3D Modeling and Structural Monitoring of the Puka Pukara Archaeological Complex-Peru
}

\author{
Rolando Mamani-Huaman*, Hernan Chavez Rojas, Mariel P. Ramos Inche \\ Department of Engineering, Professional Academic School of Civil Engineering, Universidad Continental, Huancayo, Peru
}

Received December 16, 2021; Revised January 11, 2022; Accepted February 20, 2022

\section{Cite This Paper in the following Citation Styles}

(a): [1] Rolando Mamani-Huaman, Hernan Chavez Rojas, Mariel P. Ramos Inche, "3D Modeling and Structural Monitoring of the Puka Pukara Archaeological Complex-Peru," Civil Engineering and Architecture, Vol. 10, No. 2, pp. 407-414, 2022. DOI: 10.13189/cea.2022.100201.

(b): Rolando Mamani-Huaman, Hernan Chavez Rojas, Mariel P. Ramos Inche (2022). 3D Modeling and Structural Monitoring of the Puka Pukara Archaeological Complex-Peru. Civil Engineering and Architecture, 10(2), 407-414. DOI: 10.13189/cea.2022.100201.

Copyright $\mathrm{C} 2022$ by authors, all rights reserved. Authors agree that this article remains permanently open access under the terms of the Creative Commons Attribution License 4.0 International License

\begin{abstract}
Archaeological buildings are part of our national cultural heritage, have a legacy of historical significance, and are generators of economic benefits, due to tourist movements. Three-dimensional models have become a useful and significant tool for monitoring records, virtual reality, and structural analysis of architectural monuments. Aerial photogrammetry is the most employed method, it provides a complete model of the monument, incorporates a digital camera that can be used manually, placed on a drone, or on top of tripod instruments. Therefore, this method is versatile and can generate complete 3D models at the expense of longer processing times. This study proposes the 3D modeling and structural monitoring of the archaeological complex of Puka Pukara, to characterize the general state of damage of the monument, including inaccessible areas. The data generated from the area acquisition provided a thorough identification of the pathologies in the facades and walls. The results show highly deterministic 3D digital models that are then rigorously analyzed. The structural monitoring showed that the west wall and the east façade of the Puka Pukara enclosure show deterioration, cracks, deformations, and a high risk of decline, so emergency actions are recommended for their stabilization. The paper presented a single case study where a single 3D scanning technique was applied to the archaeological complex of Puka Pukara. The results generated by the methodology allowed complete digitization (exterior and interior) with a high level of detail of the structures, which can only be achieved by using one methodology (photogrammetry).
\end{abstract}

Keywords Photogrammetry, Drone, 3D Modeling, Structural Monitoring, Archaeological Complex, Enclosure, Architectural Monument

\section{Introduction}

In Peru, there are several remains of cultural heritage among which are the historical monuments of stone masonry, built by our ancestors in different cultural horizons. When exposed to natural phenomena, they run the risk of being damaged or even disappearing. Among these phenomena, we have earthquakes, which are recurrent in Peru. To protect these buildings from earthquakes, interdisciplinary studies are required to propose measures to guarantee their structural integrity. These measures are very necessary since over time the historical buildings suffered the onslaught of nature, which in many cases were seismic actions. Therefore, their original resistant capacity was affected. For these reasons, over the years, the scientific society has focused its attention on 3D modeling techniques, conservation, structural analysis, and other related studies [1], [2], [3], [4], [5]. Three-dimensional modeling is a general method for conservation and reconstructions of archaeological heritage due to its importance largely in digitized models. This methodology has advantages and disadvantages and its use is determined by the application, budget, and accuracy requested for the project. 
The application of 3D modeling can be found in several disciplines. In Architecture, it is used to generate digital models, from which drawings can be produced [6], [7], [8], [9], [10], [11]. In engineering, they are applied to build solid models for finite element analysis (FEA) [6] and update solid models with new geometrical information [12], [13]. Photogrammetry was used to record vernacular buildings. This provided a more adequate preservation mechanism and a maintenance approach likely to locate damage in different typologies of buildings with facades [14], [15], [16]. This research was carried out following the methodology and parameters recommended for internal guidance by [17] and [18], [19].

\section{Materials and Methods}

The modeling process followed for the studied case arose according to what was foreseen in the data acquisition, a single methodology was applied according to the desired final result and the characteristics of the worksite. Table 1 presents a suitable $3 \times 3$ rule methodology and the process applied for the 3D modeling of the archaeological monument.

Table 1. Methodology and photogrammetric parameters

\begin{tabular}{|c|c|}
\hline Rules & Specifications \\
\hline \multirow{3}{*}{ 1. Geometries } & $\begin{array}{l}\text { Identify various routes and establish } \\
\text { them or make plumbed orientations. }\end{array}$ \\
\hline & $\begin{array}{l}\text { Take pictures every } 0^{\circ}-30^{\circ}-45^{\circ} \text { or } \\
\text { every } 1 / \text { to } 1 / 150 \text { of distance. }\end{array}$ \\
\hline & $\begin{array}{l}\text { Capture normal photographs of the } \\
\text { objects under study. }\end{array}$ \\
\hline \multirow{3}{*}{ 2. Photographs } & $\begin{array}{l}\text { Keep internal parameters steady (no } \\
\text { zooming, keep the focus steady or } \\
\text { undefined). }\end{array}$ \\
\hline & $\begin{array}{l}\text { Avoid compact shadows, look for good } \\
\text { lighting (internal and external). }\end{array}$ \\
\hline & $\begin{array}{l}\text { Use a good camera. Do not edit or crop } \\
\text { the photographs. }\end{array}$ \\
\hline \multirow{3}{*}{ 3. Structures } & $\begin{array}{l}\text { Perform good planning and make a } \\
\text { good sketch for the case study. }\end{array}$ \\
\hline & $\begin{array}{l}\text { Note all procedures performed in the } \\
\text { field. }\end{array}$ \\
\hline & $\begin{array}{l}\text { Carefully analyze the photographs } \\
\text { before recording them on the computer. }\end{array}$ \\
\hline
\end{tabular}

Source: Arévalo Vera, B., Bayona Ibáñez, E., \& Rincón Parada, I. K. (2015). Methodology for 3D documentation using digital photogrammetry. Tecnura, 19(SPE), 113-120.

\subsection{Aerial and Terrestrial Photogrammetry}

Photogrammetry is commonly used for the digitization of $3 \mathrm{D}$ models in various applications due to the fast acquisition process and low cost of the equipment [20], [21], [22], [23]. In addition, photogrammetry offers the possibility of obtaining information from elevated spaces. However, there are certain restrictions when using aerial vehicles in areas with obstacles or nearby buildings.

The automatic generation of digital models of structures using aerial and terrestrial photogrammetry requires the application of a structured and well-applied methodology. This methodology consists of four stages: flight planning, aerial photography, ground photography, and data processing.

Flight planning is the first step of this methodology and involves the recognition of the different factors in the work area. First, it is necessary to identify the areas around the building where the flight will be executed. In addition, the desired level of detail must be specified, as this will determine whether the flight path should be focused on specific areas of the site.

During the second stage, aerial photography is performed using the flight plan developed preliminarily. During this process, it is unavoidable to define the camera tilt angle and the distance between photographs to achieve an accuracy of approximately $30 \%$ of each other. For this study, the Phantom DJI 4 RTK embedded with 1-inch 20 $\mathrm{MP} / \mathrm{UHD} 4 \mathrm{~K}$ CMOS sensor camera (focus at $1 \mathrm{~m}-\infty$ ) was used.

Data acquisition for terrestrial photogrammetry must be performed following some fundamental requirements similar to those of the aerial technique: $30 \%$ accuracy between photographs, good lighting, and photographs from different angles. However, this technique is focused on low building spaces, images are acquired by varying the elevation angle of the camera. On the cases studied, ground photographs were taken using a 20.3 MP Canon Powershot SX-540 HS camera.

Finally, data processing is achieved using specialized photogrammetry software to obtain $3 \mathrm{D}$ models. This precision process begins with the orientation of images by identifying common points. Subsequently, a dense point cloud representing the geometry of the building is obtained. From the point cloud, point triangulation is performed to generate a textured mesh that describes the building. Finally, the software textures the model based on the information from the photographs [20]. Agisoft Metashape software was used for this purpose because it allows $3 \mathrm{D}$ reconstructions under different levels of detail (LOD) [18], [24].

\section{Case Study: Puka Pukara Archaeological Complex}

\subsection{Description of the Site}

The archaeological complex of Puka Pukara is one of the main archaeological sites. It is located next to the archaeological complex of Saqsaywaman, in the district of Cusco, province of Cusco, department of Cusco. The construction of the archaeological complex of Puka Pukara has not been possible to find in any document; however, by its architectural characteristics, it could be determined that it began to be built in the periods of command of the Inca 
Pachacutec in the fifteenth century and later was completed by the Inca Huayna Capac in the sixteenth century. Also, [25] indicates that Puka Pukara is a denomination recorded in the 20th century. The Puka Pukara sector was called Tampumachay, while the place that today has that name corresponded to T'impuqpujyo. According to its geographic position and archaeological distribution, it is clear that the fundamental activity of Puka Pukara was, in the first place, a military base, as indicated by [26], by mentioning that from its predominant position the Inca roads that crossed from the provinces of Calca and Urubamba were intervened, at the same time that it allowed watching over the security and protection of the members of the royal family during their visits to the Tambomachay resort [27].

The archaeological complex of Puka Pukara according to the topography of the terrain was built with continuous foundations and retaining walls of limestone masonry, on the west side is the typical facade of the archaeological site located on top of a small square, to the opposite side of the building stands a considerable ground elevation which compromises the unevenness of the terrain. Depending on the structural requirements of each building, there are buildings with rectangular geometries, small squares, stairways, roads, bathrooms, hydraulic canals, guard posts, and an easily distinguishable Inca access, among others. The buildings are made of limestone and andesite masonry of medium and small geometries, the outer perimeter is slightly rough compared to other archaeological groups. The configuration of the urban space is eminently appropriate and practical, from the point of view of [28], [29], [30].

\subsection{Planning and Data Acquisition}

The case study involved the application of a single photogrammetry methodology. Aerial photogrammetry was used to obtain the data from elevated areas outside the building. Terrestrial photogrammetry was used to complement the data because the site was surrounded by walls and other buildings nearby, which made it difficult to obtain more accurate and detailed aerial images.

The photographic recording was carried out in two stages: obtaining aerial photographs and obtaining ground photographs. All photographs captured the areas necessary for the 3D reconstruction, as shown in Figure 1, where the blue square objects represent each photograph acquired.

A total of 100 aerial photographs were captured all around the architectural building of Puka Pukara. The angle of inclination of the camera used for the acquisition was $45^{\circ}$. The average length of the camera to the area where the architectural monument was located was 10.26 $\mathrm{m}$ and the average length between photographs was $5 \mathrm{~m}$. The flight session took approximately 10 to 15 minutes.

In addition, 40 detailed ground photographs were taken around the architectural monument, focusing on the corners between the walls and the side buildings and also on the back wall of the building. The photographs were taken at a height of $1.50 \mathrm{~m}$ with three different tilt angles at each position: $30^{\circ}, 0^{\circ}$, and $45^{\circ}$. The average length of the camera on the outside of the building was $3 \mathrm{~m}$ and the average distance between photographs was $1 \mathrm{~m}$.

Figure 1 shows the methodology followed to acquire aerial and terrestrial photographs, where the location of these photographs is represented with dark blue square objects. Here it can be seen that the flight path of the drone was focused around the building and the entire architectural monument. The ground photographs focused on the corners of the building and the back wall.
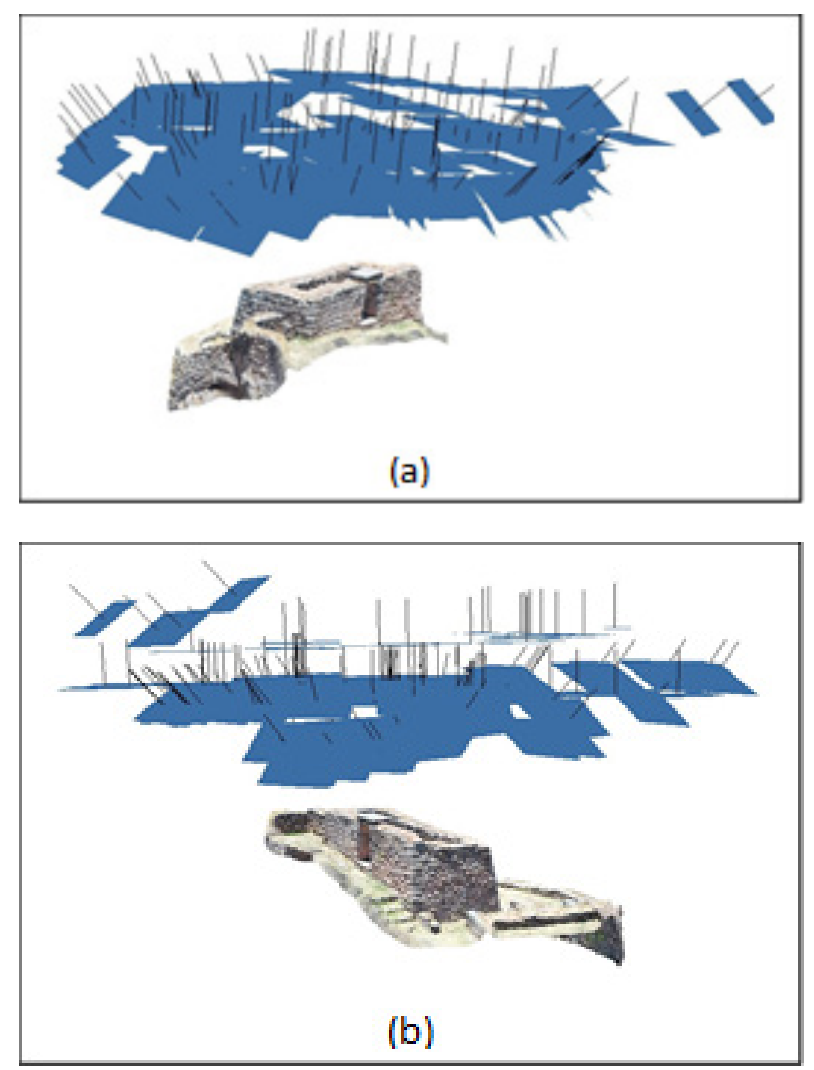

Figure 1. Image acquisition for the 3D photogrammetric reconstruction of the Puka Pukara architectural complex: (a) left isometric view. (b) right isometric view. The blue squares represent each of the acquired photographs.

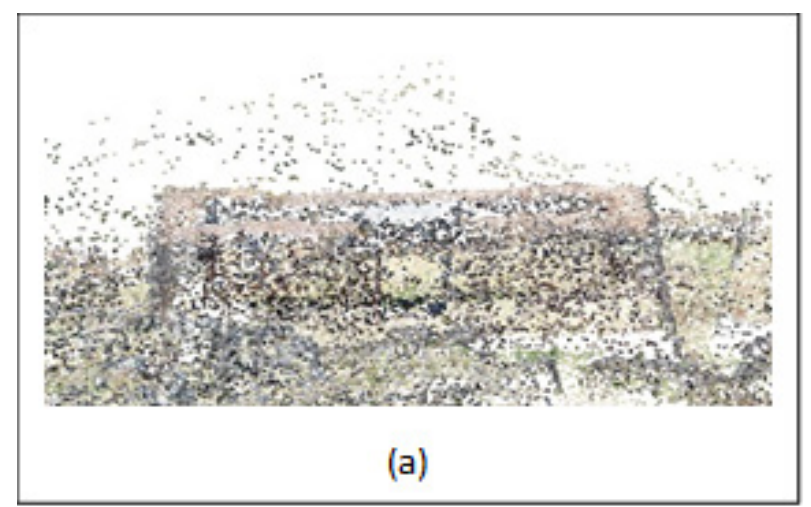



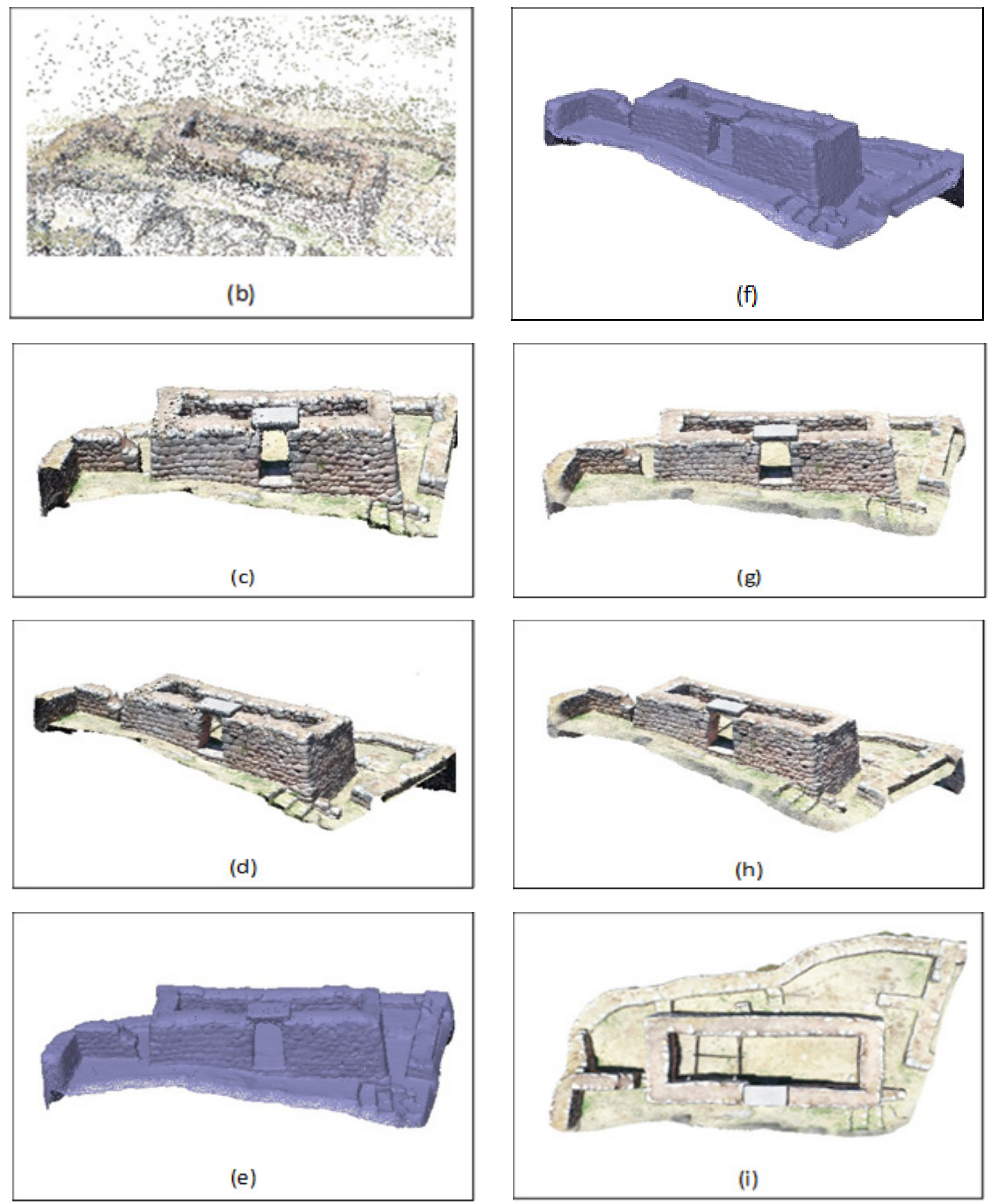


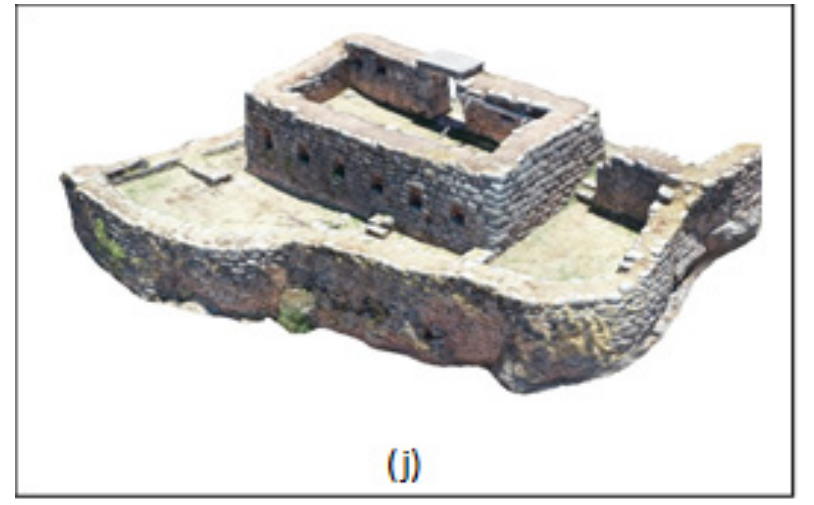

Figure 2. Photogrammetry process for the generation of models of the Puka Pukara architectural monument: scattered cloud (a) frontal and (b) isometric; dense cloud (c) frontal and (d) isometric view; triangular mesh (e) frontal and (f) isometric view; and textured model (g) frontal and (h) isometric; textured tesserae model (i) upper and (j) isometric view.

Table 2. Characteristics of the generated model of the Puka Pukara architectural monument

\begin{tabular}{ccc}
\hline Result & Characteristic & Figure \\
\hline Sparse cloud & 95,723 & $2 \mathrm{a}, 2 \mathrm{~b}$ \\
Dence cloud & $13,299,495$ & $2 \mathrm{c}, 2 \mathrm{~d}$ \\
Triangular mech & 200,497 vertex and 399,179 & $2 \mathrm{e}, 2 \mathrm{f}$ \\
faces & $2 \mathrm{~g}, 2 \mathrm{~h}$ \\
$\begin{array}{c}\text { Texturized model } \\
\text { Texturized tile } \\
\text { model }\end{array}$ & $4,096 \times 4,096$ pixels & $2 \mathrm{i}, 2 \mathrm{j}$ \\
\hline
\end{tabular}

\subsection{Model Processing and Generation}

Model generation by photogrammetry was performed following the methodology proposed for the case study. Figure 2 presents the products obtained from the steps followed in the model generation. The model was processed with high LOD to achieve greater detail. The characteristics of each step are summarized in Table 2. Due to the characteristics of the structure, the model was generated by processing separate segments that were merged at the end. The generation of the model for this case required 3 days of data processing using an HP 15-gw0012la Laptop workstation.

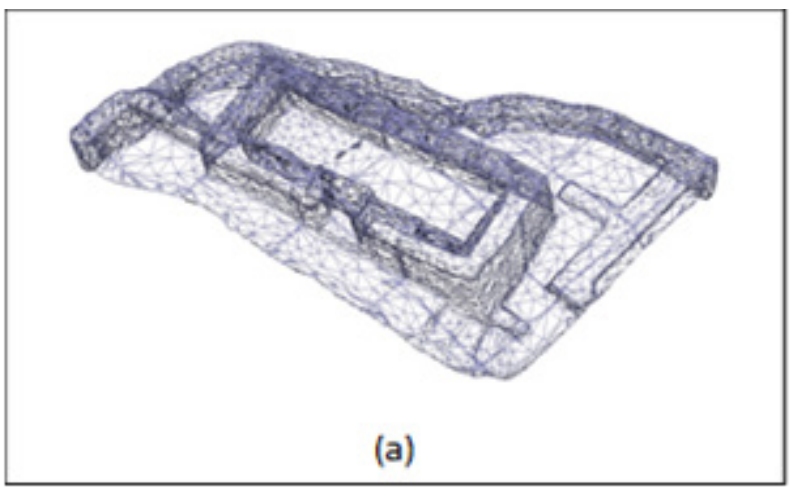

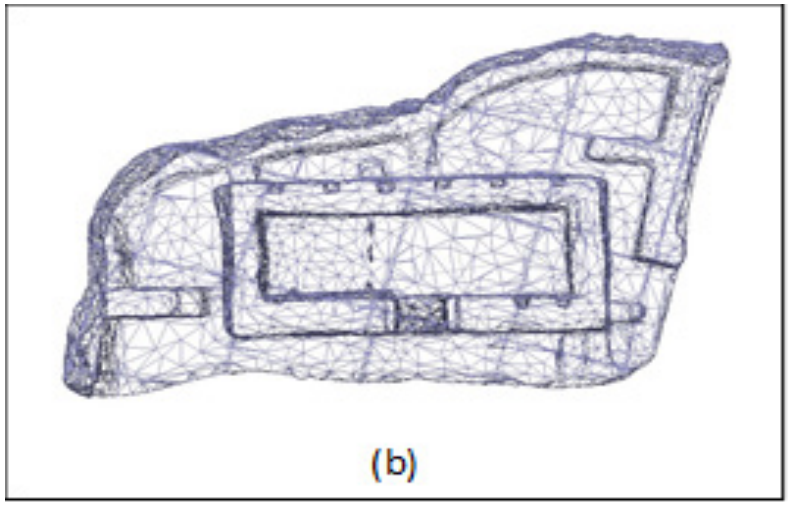
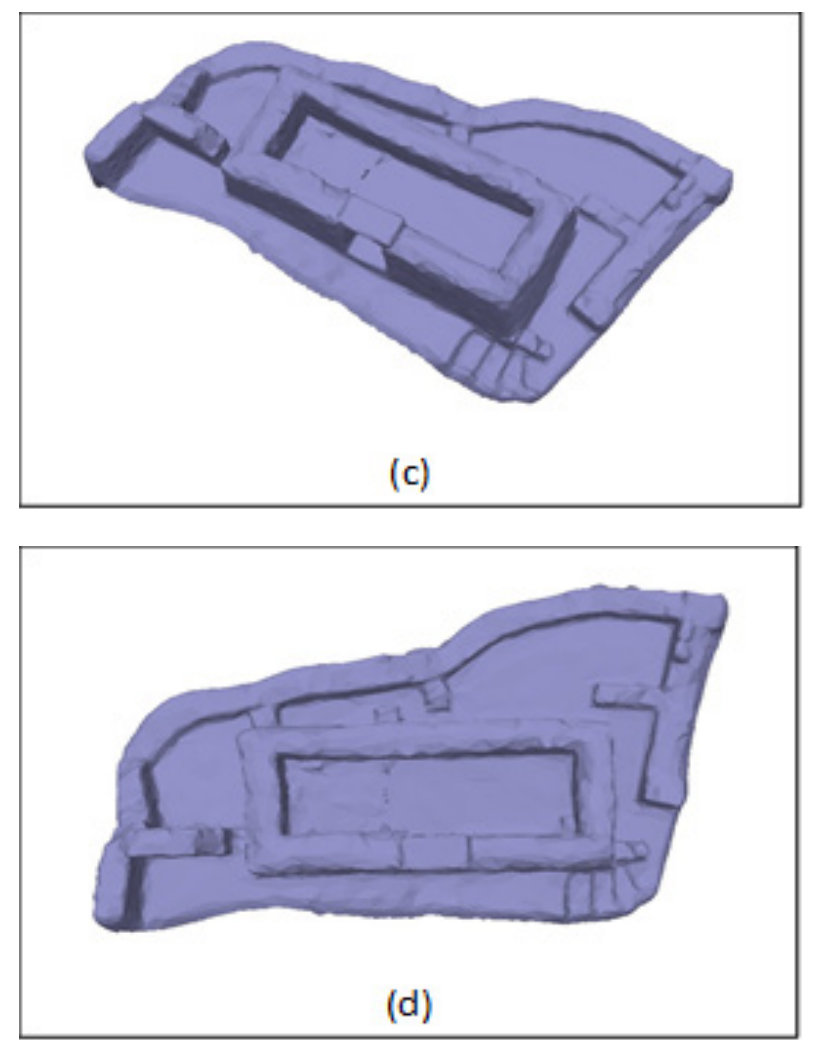

Figure 3. The model was generated using aerial photogrammetry data of the Puka Pukara architectural monument: (a) With isometric wire tesserae model and (b) top view; (c) isometric shaded tesserae model and (d) top view.

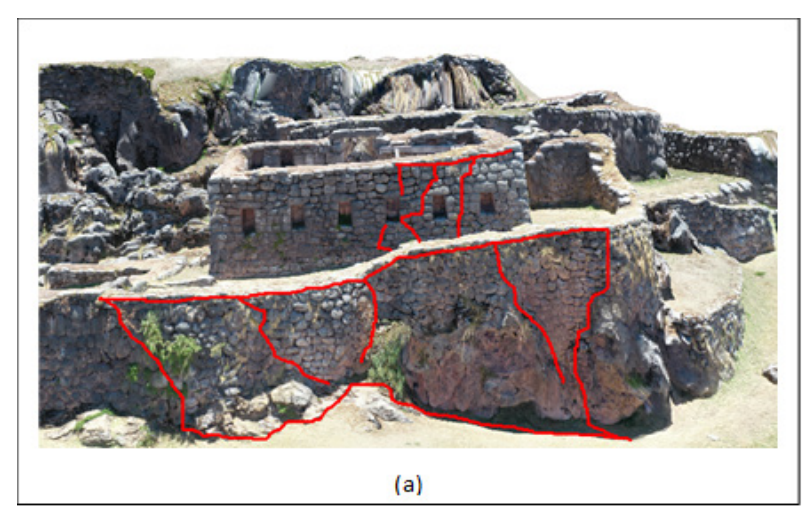




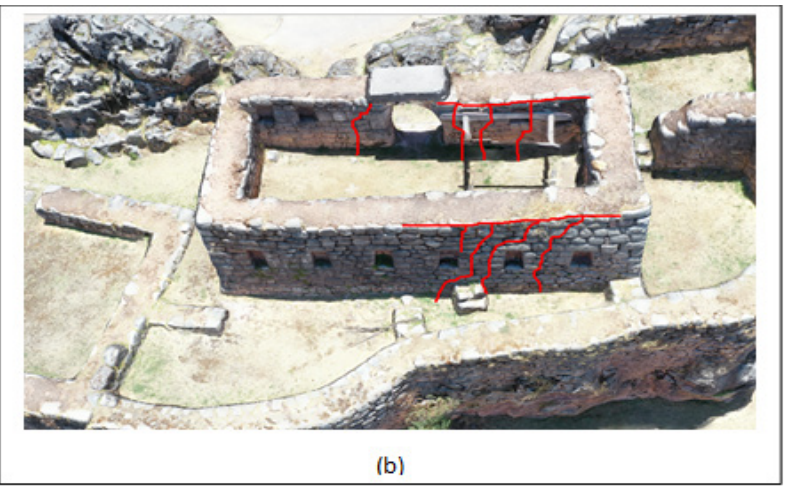

Figure 4. The model generated using aerial photogrammetry data of the Puka Pukara architectural monument: Structural monitoring showed that the west wall (a) and the east façade (b) of the Puka Pukara enclosure show deterioration, cracks, deformations, and a high risk of decline.
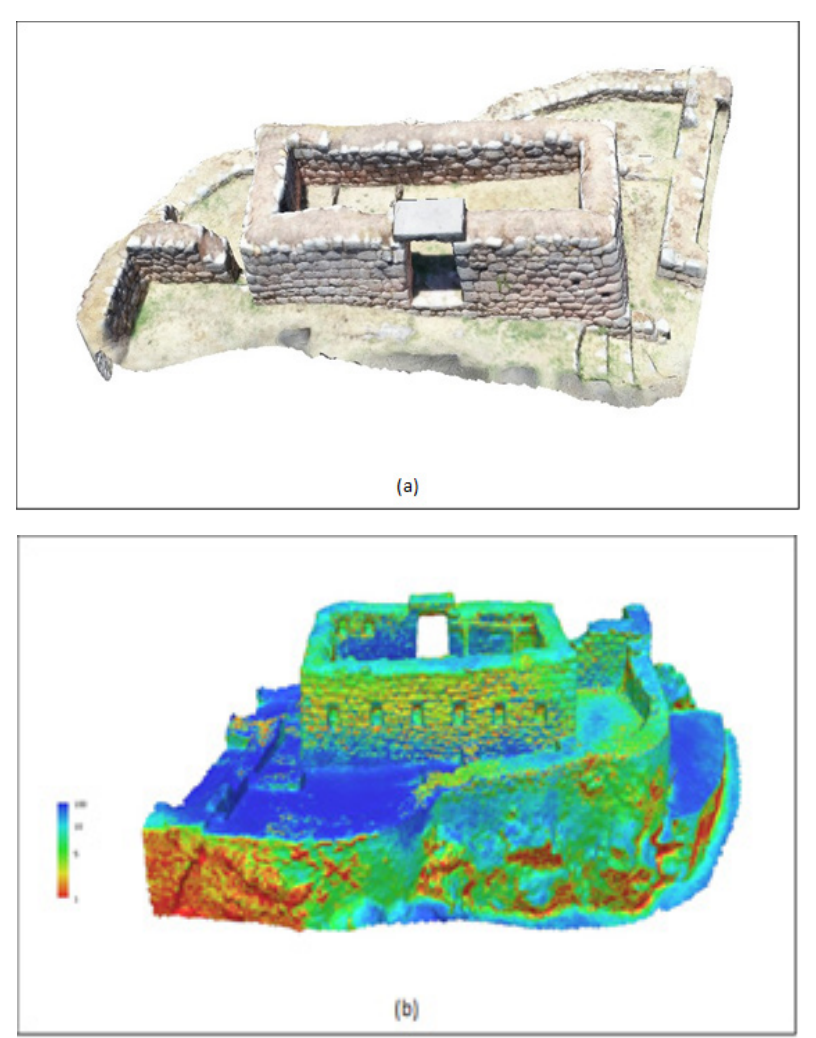

Figure 5. Combined model (a) and confidence level (b) of the Puka Pukara architectural monument using aerial and terrestrial photogrammetry.

The flight data were processed following the same procedure as the methodology proposed for the preparation of the case study. The resulting point cloud had a total of $13,299,495$ points. The products obtained from this procedure are shown in Figure 3, where it can be observed (Fig. 3a) with isometric wire tesserae model and (Fig. 3b) top view and (Fig. 3c) isometric shaded tesserae model and (Fig. 3d) top view.

A complete model was generated by combing the exterior model obtained with aerial and terrestrial photogrammetry. This model was processed using the same procedure explained in the methodology proposed for the development of the case study. Figure 5 shows the $3 \mathrm{D}$ model obtained from the process.

\subsection{Discussion}

The case was studied with the purpose and interest of monitoring structural health through the application of 3D photogrammetry. However, in this case, it was necessary to take terrestrial images because the building had multiple obstacles around it and poor lighting due to nearby buildings. For this reason, both aerial and terrestrial images were taken to model the exterior structure. This shows that, although a modeling project could have a similar structure. Multiple factors could vary the process and methodology needed to achieve the same final product.

The results show highly detailed 3D digital models that are subsequently rigorously analyzed. The structural monitoring showed that the west walls and the east façade of the Puka Pukara precinct show deterioration, cracks, deformations, and a high risk of decline, so emergency actions are recommended for their stabilization.

\section{Conclusions}

The paper presented a single case study where a single 3D scanning technique was applied to the archaeological complex of Puka Pukara. In this monument, photogrammetry was used to model the exterior and interior of the architectural enclosure. While the methodology proposed by the authors was applied to model only the exterior of the monument. The results generated by the methodology allowed a complete digitalization (exterior and interior) with a high level of detail of the structures, which can only be achieved by using one methodology (photogrammetry).

The high level of detail obtained in the digitized structures proves the capabilities of the modeling techniques and leads to the conclusion that these could be used as tools for the digitization of architectural and archaeological heritage especially in countries with a large number of cultural heritages, such as Peru. In addition, the resulting $3 \mathrm{D}$ models can be used to build solid models for finite element analysis FEA, as well as tools for planning the preservation of architectural and archaeological buildings in the face of possible natural disasters (seismic, wind, and floods).

Thus, for future research it is necessary to focus on obtaining better results, for this it is necessary to apply more sophisticated methodologies in this type of study, such as (IR Infrared Thermography) is applied to detect some possible structural failures in buildings through heat imaging, (TLS laser scanner) to obtain real results of high precision and accuracy in 3D modeling of buildings, obtaining points is high speed compared to aerial photogrammetry, which is why by applying this mixed 
methodology can obtain more optimal results and thus ensure the integrity and proper monitoring of the structural health of architectural and pre-Inca buildings.

In subsequent studies, we will compare the models generated using the mixed methodology to obtain the characteristics offered by each methodology, and based on the results we will recommend the applications in which each methodology should be used.

\section{REFERENCES}

[1] M. Pieraccini, G. Guidi and C. Atzeni, "3D digitizing of cultural heritage," Journal of Cultural Heritage, vol. 2, no. 1, pp. 63-70, 2001. doi: 10.1016/S1296-2074(01)01108-6.

[2] S. Quinto Fernández, "Use and Exploitation of New Technologies in the Conservation of Built Heritage. Review of Emblematic Cases in Perú," devenir, vol. 3, no. 5, pp. 113-132, 2016. doi: 10.21754/devenir.v3i5.290.

[3] R. Aguilar, M. F. Noel, C. Briceño, D. Arce, B. Castañeda and L. F. Ramos, "Geomatics' procedures and dynamic identification for the structural survey of the church of 'San Juan Bautista de Huaro' in Perú," 2016. doi: 10.1201/b21889-110.

[4] J. A. Benavides López, J. M. Martín Civantos and J. Rouco Collazo, "Architectural survey and archaeological analysis of the Pínar Castle as a starting point for its conservation," Virtual Archaeology Review, vol. 11, no. 22, pp. 95-115, 2020. doi: 10.4995/var.2020.12397.

[5] C. Briceño, M. Gonzales, C. Yaya, S. Moreira and R. Aguilar, "Preliminary Structural Diagnosis of the Sacsamarca Church in Peru Using Photogrammetry and IR Thermography," Structural Analysis of Historical Constructions, vol. 18, pp. 2431-2438, 2019. doi: 10.1007/978-3-319-99441-3_261.

[6] B. Babak and H. Grosman, "Drawing in Time: Processes of Design and Fabrication," Architectural Design, vol. 86, no. 1, pp. 98-107.

[7] Montero, J. Sardi and M. Augusta Hermida, "Possibilities of the three-dimensional reconstruction of heritage areas based on photogrammetry and LIDAR scanner. The Barranco of the city of Cuenca as a case study," MASKANA, vol. 8, no. 2, pp. 83-98, 2017. doi: 10.18537/mskn.08.02.07.

[8] P. Ortiz Coder and B. Del Pino Espinosa, "Automatic 3D scanning with laser scanner, photogrammetry and videogrammetry. The Temple of Diana case study (Merida).," Virtual Archaeology Review, vol. 4, no. 8, pp. 90-94, 2013. doi: 10.4995/var.2013.4325.

[9] P. Aparicio Resco, F. Espinoza Figueroa, M. Del Cisne Aguirre Ullauri, P. Mejía Coronel and C. Matovelle Jara, "Digital photogrammetry for the 3D model of the archeological site of Todos Santos, Cuenca (Ecuador)," ESTOA, vol. 7, no. 13, pp. 25-35, 2018. doi: 10.18537/est.v007.n013.a02.

[10] M. Pieraccini, G. Guidi and C. Atzeni, "3D digitizing of cultural heritage," Journal of Cultural Heritage, vol. 2, no. 1, pp. 63-70, 2001. doi: 10.1016/S1296-2074(01)01108-6.

[11] J. Á. Ruiz Sabina, D. Gallego Valle, C. Peña Ruiz, J. M. Molero García and A. Gómez Laguna, "Aerial Photogrammetry by drone in archaeological sites with large structures. Methodological approach and practical application in the medieval castles of Campo de Montiel," Virtual Archaeology Review, vol. 6, no. 13, pp. 5-19, 2015. http://hdl.handle.net/10578/9393.

[12] F. Zvietcovich, B. Castaneda and R. Perucchio, "3D solid model updating of complex ancient monumental structures based on local geometrical meshes," Digital Applications in Archaeology and Cultural Heritage, vol. 2, no. 1, pp. 12-27, 2015. doi: 10.1016/j.daach.2015.02.001.

[13] M. Burgos, B. Castaneda and R. Aguilar, "Virtual Reality for the Enhancement of Structural Health Monitoring Experiences in Historical Constructions," Structural Analysis of Historical Constructions, vol. 18, pp. 429-436, 2019. doi: 10.1007/978-3-319-99441-3 46.

[14] İ. Akbaylar and M. Hamamcioğlu-Turan, "Documentation of a Vernacular House with Close-Range Digital Photogrammetry," in XXI International CIPA Symposium, Athens, Greece, 2007. https://hdl.handle.net/11147/9849.

[15] F. Navarro Tamayo, A. L. Rodríguez Quesada and V. Ávila Ayón, "Application of digital architectural photogrammetry in the restoration of colonial buildings in the historic center of the city of Holguín, Cuba. A higher step in the conservation of architectural and cultural heritage," in 1st International Congress on Unified and Multipurpose Cadastre, 2010.

[16] Soto Martin, A. Fuentes Porto and J. Martin Gutierrez, "A Digital Reconstruction of a Historical Building and Virtual Reintegration of Mural Paintings to Create an Interactive and Immersive Experience in Virtual Reality," Applied Sciences, vol. 10, no. 2, p. 597, 2020. doi: 10.3390/app10020597.

[17] B. Arévalo Vera, E. Bayona Ibáñez and I. K. Rincón Parada, "Methodology for 3D documentation using digital photogrammetry," Tecnura, vol. 19, no. 45, pp. 113-120, 2015. doi: 10.14483/udistrital.jour.tecnura.2015.3.a09.

[18] D. Arce, S. Retamozo, R. Aguilar and B. Castañeda, "A mixed methodology for detailed 3D modeling of architectural heritage," Structural Analysis of Historical Constructions: Anamnesis, Diagnosis, Therapy, Controls, pp. 104-111, 2016. doi: 10.1201/9781315616995.

[19] D. Vargas Salvador, G. Gayoso Bazán, J. Ávalos Rodríguez and L. Costilla Mora, "Virtual reconstruction based on the aerophotogrammetric survey of the archaeological monument: Huaca El Rosario, Chicama Valley," Quingnam, vol. 4, no. 1, pp. 151-168, 2018. doi: 10.22497/quingnam.04.0404.

[20] J. De Reu, G. Plets, G. Verhoeven, P. De Smedt, M. Bats, B. Cherretté, W. De Maeyer, J. Deconynck, D. Herremans, P. Laloo and M. V. Meirvenne, "Towards a three-dimensional cost-effective registration of the archaeological heritage," Journal of Archaeological Science, vol. 40, no. 2, pp. 1108-1121, 2013. doi: 10.1016/j.jas.2012.08.040.

[21] F. Nex and F. Remondino, "UAV for 3D mapping applications: a review," Applied Geomatics, vol. 6, pp. 1-15, 2014. doi: 10.1007/s12518-013-0120-x. 
[22] F. Remondino, "Heritage Recording and 3D Modeling with Photogrammetry and 3D Scanning," Remote Sens, vol. 3, pp. 1104-1138, 2011. doi: 10.3390/rs3061104.

[23] H. Khairil Afendy, A. Anuar, S. Abd. Manan, T. Khairul Nizam and U. Wani Sofia, "Integration of Low Altitude Aerial \& Terrestrial Photogrammetry Data in 3D Heritage Building Modeling," in 2012 IEEE Control and System Graduate Research Colloquium, 2012. doi: 10.1109/ICSGRC.2012.6287166.

[24] Luis Rivas and J. Martínez Rubio, "Taking photogrammetric data, virtual reconstruction, augmented reality and dissemination on the network of the Church of Our Lady of the Assumption, Mombuey (Zamora)," Salamanca, Spain, 2013.http://hdl.handle.net/10366/12217 7.

[25] V. Angeles Vargas, Sacsayhuaman, Architectural Portento, Lima: Lima Ind. Chavin Graphics, 1990, pp. 1-184.

[26] L. A. Pardo, History and Archeology of Cuzco, vol. 1, Lima:
Leoncio Prado Military College, 1957, pp. 1-679.

[27] R. Carreño Collatupa, "Pre-hispanic archeological heritage and geodynamic hazard in the valley of Pre-hispanic archeological heritage and geodynamic hazard in the valley of," Bulletin de l'Institut français d'études andines, vol. 34, no. 1, pp. 1-31, 2005. doi: 10.4000/bifea.5580.

[28] P. Llerena Delgado, "Cultural tourist attractions in the Tambomachay ravine and proposal of a tourist circuit to promote tourist development in the producers association "Los Huertos", 2017," Cusco, 2017.

[29] R. Mar and J. A. Beltrán Caballero, "The archaeological site of Saqsaywaman (Cusco): an approach to its architecture," Spanish Journal of American Anthropology, vol. 44, no. 1, pp. 9-38, 2014. doi: 10.5209/rev_REAA.2014.v44.n1.4763 3.

[30] Abarca Ancori, Amparo, Study of soil and rock mechanics: methodology for heritage assets Saqsaywaman archaeological park - The Monument, vol. 1, Cusco, 2021. http://bvirtual.culturacusco.gob.pe, pp. 1-101. 